\title{
Comparative Effect of Banana Pseudostem Scutching Waste, FYM and Biocompost on Water Stable Aggregate (WSA) and Available Nutrients in Soil after Harvest of Cabbage
}

\author{
Lokesh Kumar Saini $^{1 *}$, J.M. Patel ${ }^{2}$ and Rameti Jangir ${ }^{1}$ \\ ${ }^{1}$ Department of Soil Science and Agricultural Chemistry, NMCA, NAU, Navsari, \\ Gujarat, India \\ ${ }^{2}$ Soil and Water Management Research Unit, NAU, Navsari, Gujarat, India \\ *Corresponding author
}

\section{A B S T R A C T}

\begin{tabular}{|c|}
\hline Keywords \\
\hline $\begin{array}{l}\text { Available nutrients, Banana } \\
\text { pseudostem scutching waste, } \\
\text { Biocompost, Carbon } \\
\text { equivalent, FYM and Water } \\
\text { Stable Aggregate (WSA) }\end{array}$ \\
\hline Article Info \\
\hline $\begin{array}{l}\text { Accepted: } \\
16 \text { April } 2018 \\
\text { Available Online: } \\
10 \text { May } 2018\end{array}$ \\
\hline
\end{tabular}

The field experiment was conducted at Soil and Water Management Farm of Navsari Agricultural University, Navsari to study the comparative effect of different organic manures on WSA and available nutrients. The experiment comprised of nine treatment of banana pseudostem scutching waste (SW), FYM and biocompost (BC) with or without combination and applied as FYM @ $10 \mathrm{t} \mathrm{ha}^{-1}$ carbon equivalent basis keeping the common dose of recommended inorganic fertilizer. After harvest of the crop there were no significant changes observed with respect to soil $\mathrm{pH}$, EC and organic carbon content of the soil. While, significantly higher values of WSA $(1.0 \mathrm{~mm}$ and $>1.0 \mathrm{~mm})$, available macronutrients $\left(\mathrm{N}, \mathrm{P}_{2} \mathrm{O}_{5}, \mathrm{~K}_{2} \mathrm{O}\right.$ and $\left.\mathrm{S}\right)$ and micronutrients $(\mathrm{Fe}, \mathrm{Mn}, \mathrm{Zn}$ and $\mathrm{Cu}$ ) content of soil were found with $100 \%$ FYM $\left(\mathrm{O}_{0}\right)$ at $0-15$ and $15-30 \mathrm{~cm}$ depth of soil and this remained statistically at par with treatment $\mathrm{O}_{2}(100 \% \mathrm{BC})$ and $\mathrm{O}_{6}(75 \% \mathrm{FYM}+25 \% \mathrm{SW})$ in almost all the cases.

\section{Introduction}

Lack of adequate nutrient supply and poor soil structure are the main constraints to agricultural production systems in low-input agriculture. Chemical fertilizers and organic manures play a pivotal role in vegetable production and nutrient supply system is considered as one of the basic factor. It has been established beyond doubt that there is a positive correlation between fertilizer use and crop productivity. Farmers are using excessive chemical fertilizers leading to decline in soil organic carbon. The excessive uses of chemical fertilizers disrupt the structure and other physico-chemical properties of the soil and serious damage to ecology. Therefore, use of chemical fertilizer alone may not keep pace with time in maintenance of soil health for sustaining the productivity. Integrated use of organic and inorganic source of nutrient in vegetables is superior in application to chemical fertilizer alone (Sharma et al., 2012).

The use of organic manures improves soil health and help in maximizing production. It involves utilization of local sources and hence, turned to be rational, realistic and amendment 
for soil. Integrated application of diverse source of nutrients improve the post-harvest soil fertility and subsequently helps for achieving much desired crop production with sustainable soil health (Chatterjee and Bandyopadhyay, 2014).

Presently, the banana pseudostem (60 to $80 \mathrm{t}$ $\mathrm{ha}^{-1}$ ) is absolute waste in most of the banana growing states of India. Disposal of pseudostem in a routine ways i.e., dumping on field bunds and burning, disposing in nalla/natural drains etc. causing environmental problems (Anon., 2014). Use of banana pseudostem scutching waste (30-35 $\mathrm{t} \mathrm{ha}^{-1}$ ) as an organic for crop production at large scale can solve the problem of disposal of wastes and lack of organic matter in soil. On the other hand, a judicious combination of different organic and inorganic sources of nutrients might be helpful to obtain a good soil health for the subsequent crops.

\section{Materials and Methods}

Field experiment was conducted during the rabi season of 2015-16 at Soil and Water Management Farm of Navsari Agricultural University, Navsari, Gujarat. The soil of experimental field was clay in texture with $\mathrm{pH}_{2.5} 8.3, \mathrm{EC}_{2.5}$ of $0.4 \mathrm{ds} \mathrm{m}^{-1}$ and organic carbon $0.62 \%$. The experiment soil was low in available nitrogen $\left(246 \mathrm{~kg} \mathrm{ha}^{-1}\right)$ and sulphur (6 $\mathrm{mg} \mathrm{kg}^{-1}$ ), medium in available phosphorus (45 $\left.\mathrm{kg} \mathrm{ha}^{-1}\right)$ and manganese $\left(8 \mathrm{mg} \mathrm{kg}^{-1}\right)$ and high in available potassium $\left(410 \mathrm{~kg} \mathrm{ha}^{-1}\right)$, iron (14 $\left.\mathrm{mg} \mathrm{kg}^{-1}\right)$, zinc $\left(1.2 \mathrm{mg} \mathrm{kg}^{-1}\right)$ and copper (3 mg $\left.\mathrm{kg}^{-1}\right)$. The experiment comprised of nine treatments of FYM, biocompost (BC) and banana pseudostem scutching waste (SW) and it's combinations viz., $100 \%$ FYM $\left(\mathrm{O}_{0}\right), 100 \%$ $\mathrm{SW}\left(\mathrm{O}_{1}\right), 100 \% \mathrm{BC}\left(\mathrm{O}_{2}\right), 75 \% \mathrm{BC}+25 \% \mathrm{SW}$ $\left(\mathrm{O}_{3}\right), 50 \% \mathrm{BC}+50 \% \mathrm{SW}\left(\mathrm{O}_{4}\right), 25 \% \mathrm{BC}+$ $75 \% \mathrm{SW}\left(\mathrm{O}_{5}\right), 75 \% \mathrm{FYM}+25 \% \mathrm{SW}\left(\mathrm{O}_{6}\right)$, $50 \% \mathrm{FYM}+50 \% \mathrm{SW}\left(\mathrm{O}_{7}\right)$ and $25 \% \mathrm{FYM}+$ $75 \%$ SW $\left(\mathrm{O}_{8}\right)$ were applied as basal on $10 \mathrm{t}$ $\mathrm{ha}^{-1}$ FYM carbon equivalent basis with common dose of recommended fertilizer (100:50:50 N, $\mathrm{P}_{2} \mathrm{O}_{5}, \mathrm{~K}_{2} \mathrm{O} \mathrm{kg} \mathrm{ha}{ }^{-1}$ ).

Treatments were evaluated in randomized block design with three replications on cabbage variety "Golden Acre". In the experiment fresh banana pseudostem scutching waste was used which consist of pithy matter and cut fibers generated during fiber extraction from banana pseudostem. Chemical compositions of organic manures used in the experiment are given in Table 1. The methods follow for available nutrient estimation in soil samples were given in Table 2. Data pertaining to different parameters were statistically analyzed as per the methods described by Panse and Sukhatme (1967).

\section{Results and Discussion}

\section{Water stable aggregates (WSA)}

Application of $100 \%$ FYM gave significantly higher values of WSA fraction in the range $0.5-1.0 \mathrm{~mm}(23.3 \%)$ and $>1.0 \mathrm{~mm}(59.3 \%)$ and was found to be at par with treatments $\mathrm{O}_{2}$, $\mathrm{O}_{3}$ and $\mathrm{O}_{6}$ in case of $0.5-1.0 \mathrm{~mm}$ fraction and $\mathrm{O}_{2}$ and $\mathrm{O}_{6}$ in case of $>1.0 \mathrm{~mm}$ fraction of WSA (Fig. 1). The beneficial effect of organic matter on aggregate stability was due to formation of clay-humus complexes (through binding of polyvalent cations adsorbed on clay surface) which would orient the chelating acidic functional group of humic material (carboxylic and phenols) towards the interior of aggregate, leaving aliphatic and aromatic hydrophobic components to face outward. This ultimately leaded to the formation of a water repellent coating with high surface tension, effectively reducing the water infiltration in to the aggregates and thereby improving stability of the aggregates. Angers and Carter (1996), Patel (2010) and Anon. (2013) also reported similar association between organic carbon and WSA. 
Table.1 Composition of organics manures used in the experiment

\begin{tabular}{|l|c|c|c|}
\hline \multicolumn{1}{|c|}{ Parameters } & FYM & Biocompost & Scutching waste \\
\hline $\mathrm{OC}(\%)$ & 21.55 & 25.05 & 34.45 \\
\hline $\mathbf{N}(\%)$ & 1.20 & 1.15 & 0.90 \\
\hline $\mathbf{P}_{2} \mathbf{O}_{5}(\%)$ & 0.40 & 0.35 & 0.20 \\
\hline $\mathrm{K}_{2} \mathrm{O}(\%)$ & 0.50 & 0.45 & 0.59 \\
\hline $\mathrm{Fe}\left(\mathrm{mg} \mathrm{kg}^{-1}\right)$ & 3592 & 7706 & 1228 \\
\hline $\mathrm{Mn}\left(\mathrm{mg} \mathrm{kg}^{-1}\right)$ & 531 & 470 & 60 \\
\hline $\mathrm{Zn}\left(\mathrm{mg} \mathrm{kg}^{-1}\right)$ & 150 & 182 & 6 \\
\hline $\mathrm{Cu}\left(\mathrm{mg} \mathrm{kg}^{-1}\right)$ & 49 & 89 & 8 \\
\hline $\mathrm{C}: \mathrm{N}$ ratio & 18 & 22 & 38 \\
\hline
\end{tabular}

Table.2 Methods followed for soil analysis

\begin{tabular}{|c|c|c|c|}
\hline Sr. No. & $\begin{array}{l}\text { Parameter } \\
\text { analyzed }\end{array}$ & Method followed & Reference \\
\hline 1. & WSA & Wet sieving & Black (1965) \\
\hline 2 & $\mathrm{pH}_{2.5}$ & Potentiometric & Jackson (1973) \\
\hline 3 & $\mathrm{EC}_{2.5}$ & Conductometric & Jackson (1973) \\
\hline 5 & Organic carbon & Walkley and Black titration (Modified) & Jackson (1973) \\
\hline 6 & Available $\mathrm{N}$ & Alkaline permanganate & Subbiah and Asija (1956) \\
\hline 7 & Available $\mathrm{P}_{2} \mathrm{O}_{5}$ & Olsen's method & Olsen et al., (1954) \\
\hline 8 & Available $\mathrm{K}_{2} \mathrm{O}$ & $\begin{array}{l}\text { Extraction with } 1 \mathrm{~N} \mathrm{NH}_{4} \mathrm{OAc}(\mathrm{pH} 7) \text {, Flame } \\
\text { photometric }\end{array}$ & Jackson (1973) \\
\hline 9 & Available S & Turbidimetric (extraction with $0.15 \% \mathrm{CaCl}_{2}$ ) & Chaudhary and Cornfield (1966) \\
\hline 10 & $\mathrm{Fe}, \mathrm{Mn}, \mathrm{Zn}$ and $\mathrm{Cu}$ & $\begin{array}{l}\text { Extraction with DTPA and estimation with } \\
\text { Atomic absorption spectrophotometer }\end{array}$ & Lindsay and Norwell (1978) \\
\hline
\end{tabular}

Table.3 Effect of organic manures on WSA, soil $\mathrm{pH}_{2.5}, \mathrm{EC}_{2.5}$ and organic carbon of cabbage field after harvest

\begin{tabular}{|l|}
\hline Treatments \\
\hline$O_{0}: 100 \% \mathrm{FYM}$ \\
\hline$O_{1}: 100 \% \mathrm{SW}$ \\
\hline$O_{2}: 100 \% \mathrm{BC}$ \\
\hline $\mathrm{O}_{3}: 75 \% \mathrm{BC}+25 \% \mathrm{SW}$ \\
\hline $\mathrm{O}_{4}: 50 \% \mathrm{BC}+50 \% \mathrm{SW}$ \\
\hline $\mathbf{O}_{5}: 25 \% \mathrm{BC}+75 \% \mathrm{SW}$ \\
\hline$O_{6}: 75 \% \mathrm{FYM}+25 \% \mathrm{SW}$ \\
\hline $\mathrm{O}_{7}: 50 \% \mathrm{FYM}+50 \% \mathrm{SW}$ \\
\hline $\mathrm{O}_{8}: 25 \% \mathrm{FYM}+75 \% \mathrm{SW}$ \\
\hline $\mathrm{SEm} \pm$ \\
\hline $\mathrm{CD}$ at $5 \%$ \\
\hline CV $\%$ \\
\hline
\end{tabular}

\begin{tabular}{|c|c|c|c|c|c|}
\hline \multicolumn{3}{|c|}{$0-15 \mathrm{~cm}$} & \multicolumn{3}{|c|}{$15-30 \mathrm{~cm}$} \\
\hline $\mathrm{pH}_{2.5}$ & $\begin{array}{c}\mathrm{EC}_{2.5} \\
\left(\mathrm{dS} \mathrm{m}^{-1}\right)\end{array}$ & $\mathrm{OC}(\%)$ & $\mathrm{pH}_{2.5}$ & $\begin{array}{c}\mathrm{EC}_{2.5} \\
\left(\mathrm{dS} \mathrm{m}^{-1}\right)\end{array}$ & $\begin{array}{l}\mathrm{OC} \\
(\%)\end{array}$ \\
\hline 8.1 & 0.50 & 0.77 & 8.2 & 0.33 & 0.53 \\
\hline 8.3 & 0.41 & 0.65 & 8.3 & 0.33 & 0.49 \\
\hline 8.2 & 0.45 & 0.71 & 8.2 & 0.33 & 0.53 \\
\hline 8.2 & 0.43 & 0.76 & 8.2 & 0.31 & 0.48 \\
\hline 8.2 & 0.42 & 0.72 & 8.2 & 0.34 & 0.46 \\
\hline 8.3 & 0.40 & 0.70 & 8.3 & 0.30 & 0.47 \\
\hline 8.1 & 0.50 & 0.68 & 8.2 & 0.32 & 0.53 \\
\hline 8.3 & 0.41 & 0.68 & 8.3 & 0.28 & 0.45 \\
\hline 8.3 & 0.42 & 0.75 & 8.2 & 0.32 & 0.49 \\
\hline 0.052 & 0.024 & 0.037 & 0.021 & 0.010 & 0.026 \\
\hline NS & NS & NS & NS & NS & NS \\
\hline 1.10 & 9.31 & 8.89 & 0.45 & 5.69 & 9.17 \\
\hline
\end{tabular}


Table.4 Effect of organic manures on available $\mathrm{N}\left(\mathrm{kg} \mathrm{ha}^{-1}\right), \mathrm{P}_{2} \mathrm{O}_{5}\left(\mathrm{~kg} \mathrm{ha}^{-1}\right), \mathrm{K}_{2} \mathrm{O}\left(\mathrm{kg} \mathrm{ha}^{-1}\right)$ and $\mathrm{S}$ $\left(\mathrm{mg} \mathrm{kg}^{-1}\right)$ content of cabbage field after harvest

\begin{tabular}{|c|c|c|c|c|c|c|c|c|}
\hline \multirow[t]{2}{*}{ Treatments } & \multicolumn{4}{|c|}{$0-15 \mathrm{~cm}$} & \multicolumn{4}{|c|}{$15-30 \mathrm{~cm}$} \\
\hline & $\mathbf{N}$ & $\mathbf{P}_{2} \mathbf{O}_{5}$ & $\mathrm{~K}_{2} \mathrm{O}$ & $\mathbf{S}$ & $\mathbf{N}$ & $\mathbf{P}_{2} \mathbf{O}_{5}$ & $\mathbf{K}_{2} \mathbf{O}$ & $\mathbf{S}$ \\
\hline $\mathrm{O}_{0}: 100 \%$ FYM & 278.33 & 70.02 & 480.67 & 10.17 & 203.25 & 53.26 & 428.24 & 8.30 \\
\hline $\mathrm{O}_{1}: 100 \% \mathrm{SW}$ & 251.65 & 45.00 & 420.88 & 6.60 & 169.84 & 29.76 & 354.00 & 4.91 \\
\hline $\mathrm{O}_{2}: 100 \% \mathrm{BC}$ & 268.33 & 62.67 & 463.31 & 10.10 & 193.45 & 48.33 & 410.83 & 8.02 \\
\hline $\mathrm{O}_{3}: 75 \% \mathrm{BC}+25 \% \mathrm{SW}$ & 260.67 & 55.33 & 449.10 & 9.27 & 185.76 & 40.33 & 373.33 & 7.00 \\
\hline $\mathrm{O}_{4}: 50 \% \mathrm{BC}+\mathbf{5 0 \%} \mathrm{SW}$ & 258.04 & 55.00 & 440.40 & 8.40 & 179.20 & 33.26 & 370.66 & 6.93 \\
\hline $\mathrm{O}_{5}: 25 \% \mathrm{BC}+75 \% \mathrm{SW}$ & 257.67 & 47.68 & 425.63 & 6.64 & 177.92 & 32.51 & 368.33 & 5.70 \\
\hline $\begin{array}{l}\mathrm{O}_{6}: 75 \% \text { FYM }+25 \% \\
\text { SW }\end{array}$ & 264.74 & 60.02 & 464.30 & 9.83 & 197.37 & 46.92 & 402.21 & 8.10 \\
\hline $\begin{array}{l}\mathrm{O}_{7}: \mathbf{5 0} \% \text { FYM }+\mathbf{5 0 \%} \\
\text { SW }\end{array}$ & 261.74 & 47.54 & 448.38 & 6.79 & 187.07 & 36.00 & 372.93 & 5.40 \\
\hline $\begin{array}{l}\mathrm{O}_{8}: 25 \% \text { FYM }+75 \% \\
\text { SW }\end{array}$ & 253.00 & 44.61 & 444.84 & 7.20 & 182.04 & 33.92 & 362.19 & 4.97 \\
\hline SEm \pm & 5.043 & 3.906 & 10.057 & 0.503 & 4.587 & 2.415 & 9.487 & 0.385 \\
\hline C.D. at $5 \%$ & 15.12 & 11.71 & 30.15 & 1.51 & 13.75 & 7.24 & 28.44 & 1.15 \\
\hline C.V. \% & 3.34 & 12.48 & 3.88 & 10.46 & 4.27 & 10.63 & 4.30 & 10.11 \\
\hline
\end{tabular}

Table.5 Effect of organic manures on available $\mathrm{Fe}, \mathrm{Mn}, \mathrm{Zn}$ and $\mathrm{Cu}$ content $\left(\mathrm{mg} \mathrm{kg}^{-1}\right)$ in soil after harvest of cabbage

\begin{tabular}{|c|c|c|c|c|c|c|c|c|}
\hline \multirow[t]{2}{*}{ Treatments } & \multicolumn{4}{|c|}{$0-15 \mathrm{~cm}$} & \multicolumn{4}{|c|}{$15-30 \mathrm{~cm}$} \\
\hline & $\mathrm{Fe}$ & Mn & Zn & $\mathrm{Cu}$ & $\mathbf{F e}$ & Mn & Zn & $\mathrm{Cu}$ \\
\hline $0_{0}: 100 \%$ FYM & 16.76 & 10.06 & 1.68 & 4.62 & 11.99 & 8.35 & 1.05 & 3.90 \\
\hline $\mathrm{O}_{1}: 100 \% \mathrm{SW}$ & 13.90 & 6.67 & 1.00 & 3.60 & 9.06 & 5.97 & 0.72 & 2.91 \\
\hline $\mathrm{O}_{2}: 100 \% \mathrm{BC}$ & 15.98 & 9.32 & 1.56 & 4.46 & 11.95 & 8.23 & 0.96 & 3.72 \\
\hline $\mathrm{O}_{3}: 75 \% \mathrm{BC}+25 \% \mathrm{SW}$ & 14.90 & 7.80 & 1.29 & 4.28 & 10.27 & 7.96 & 0.89 & 3.54 \\
\hline $\mathrm{O}_{4}: \mathbf{5 0} \% \mathrm{BC}+\mathbf{5 0} \% \mathrm{SW}$ & 14.52 & 7.33 & 1.19 & 4.12 & 10.32 & 6.87 & 0.86 & 3.52 \\
\hline $\mathrm{O}_{5}: 25 \% \mathrm{BC}+75 \% \mathrm{SW}$ & 13.85 & 6.80 & 1.10 & 3.86 & 9.39 & 6.13 & 0.78 & 3.33 \\
\hline $\begin{array}{l}\mathrm{O}_{6}: 75 \% \text { FYM }+25 \% \\
\text { SW }\end{array}$ & 16.42 & 9.31 & 1.55 & 4.46 & 11.55 & 8.23 & 0.96 & 3.75 \\
\hline $\begin{array}{l}\mathbf{O}_{7}: 50 \% \text { FYM }+\mathbf{5 0 \%} \\
\text { SW }\end{array}$ & 14.42 & 8.10 & 1.26 & 4.08 & 10.50 & 7.00 & 0.83 & 3.53 \\
\hline $\begin{array}{l}\mathrm{O}_{8}: 25 \% \text { FYM }+75 \% \\
\mathrm{SW}\end{array}$ & 13.95 & 6.87 & 1.19 & 4.00 & 9.81 & 6.81 & 0.79 & 3.47 \\
\hline SEm \pm & 0.299 & 0.289 & 0.051 & 0.105 & 0.295 & 0.242 & 0.036 & 0.116 \\
\hline C.D. at 5\% & 0.90 & 0.87 & 0.15 & 0.32 & 0.89 & 0.72 & 0.11 & 0.35 \\
\hline C.V. \% & 3.46 & 6.24 & 6.79 & 4.38 & 4.85 & 5.75 & 7.22 & 5.69 \\
\hline
\end{tabular}


Fig.1 Effect of different organic manures on WSA of soil after harvest of cabbage

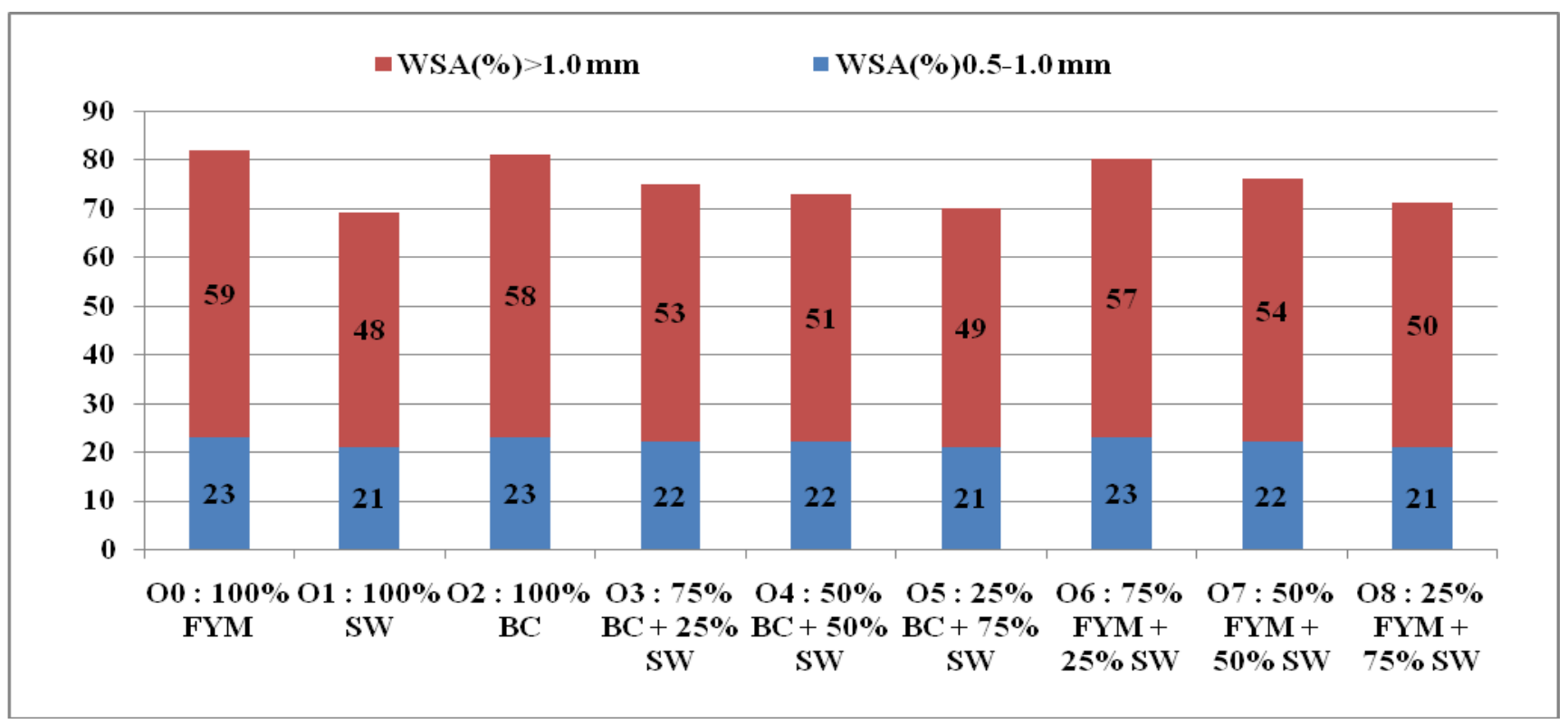

Soil pH, EC and organic carbon

The results presented in Table 3 revealed that application of different organic manures were failed to exert any significant effect on soil reaction $\left(\mathrm{pH}_{2.5}\right)$, electrical conductivity $\left(\mathrm{EC}_{2.5}\right)$ and organic carbon (OC) content in soil at both 0-15 and $15-30 \mathrm{~cm}$ depth.

\section{Available macronutrients}

Application of $100 \%$ FYM gave significantly higher value of available $\mathrm{N}$ (278.33 and 203.25 $\left.\mathrm{kg} \quad \mathrm{ha}^{-1}\right), \quad \mathrm{P}_{2} \mathrm{O}_{5} \quad(70.02$ and $53.26 \quad \mathrm{~kg}$ $\left.\mathrm{ha}^{-1}\right), \mathrm{K}_{2} \mathrm{O}$ (480.67 and $428.24 \mathrm{~kg} \mathrm{ha}^{-1}$ ) and $\mathrm{S}$ (10.17 and $8.30 \mathrm{mg} \mathrm{kg}^{-1}$ ) content at $0-15$ and $15-30 \mathrm{~cm}$ depths of soil and remained at par with the treatments $\mathrm{O}_{2}$ and $\mathrm{O}_{6}$ in case of $\mathrm{N}$, $\mathrm{P}_{2} \mathrm{O}_{5}, \mathrm{~K}_{2} \mathrm{O}$ at $0-15$ and $15-30 \mathrm{~cm}$ and in case of $\mathrm{S} \mathrm{O}_{2}$ and $\mathrm{O}_{6}$ at $0-15 \mathrm{~cm}$ and $\mathrm{O}_{2}, \mathrm{O}_{3}$ and $\mathrm{O}_{6}$ at 15$30 \mathrm{~cm}$ depth of soil (Table 4). This might be due to incorporation of low $\mathrm{C}$ : $\mathrm{N}$ ratio containing organic manures in soil which hastened the mineralization process. This resulted in conversion of organic form of nutrient into inorganic form and thus nutrient availability in soil increased. These results are corroborating well with the results of Kanwer and Paliyal (2005), Prativa and Bhattarai (2011), Leninraja (2013) and Chatterjee and Bandyopadhyay (2014).

\section{Available micronutrients}

Application of $100 \%$ FYM $\left(\mathrm{O}_{0}\right)$ gave significantly higher value of available Fe (16.76 and $\left.11.99 \mathrm{mg} \mathrm{kg}^{-1}\right), \mathrm{Mn}\left(10.06\right.$ and $8.35 \mathrm{mg} \mathrm{kg}^{-}$ $\left.{ }^{1}\right), \mathrm{Zn}\left(1.68\right.$ and $\left.1.05 \mathrm{mg} \mathrm{kg}^{-1}\right)$ and $\mathrm{Cu}$ (4.62 and $\left.3.90 \mathrm{mg} \mathrm{kg}^{-1}\right)$ content at $0-15$ and $15-30 \mathrm{~cm}$ depths of soil. However, the treatment $\mathrm{O}_{0}$ remained at par with the treatments $\mathrm{O}_{2}$ and $\mathrm{O}_{6}$ in case of $\mathrm{Fe}, \mathrm{Zn}$ and $\mathrm{Cu}$ at their respective depths. In case of $\mathrm{Mn}, \mathrm{O}_{0}$ treatment remained at par with $\mathrm{O}_{2}$ and $\mathrm{O}_{6}$ at $0-15 \mathrm{~cm}$ and $\mathrm{O}_{2}, \mathrm{O}_{3}$ and $\mathrm{O}_{6}$ at $15-30 \mathrm{~cm}$ depth of soil (Table 5). Micronutrients status of soil in organically treated plots might be due to release of chelating agents from organic matter decomposition which might have prevented micronutrients from precipitation, oxidation and leaching. Almost similar results were also reported by Patel (2010) and Anon. (2013).

On the basis of result obtained in present field investigation, it is concluded that basal application of organic manures in form of $100 \%$ 
FYM or $100 \%$ biocompost or $75 \% \mathrm{FYM}+25 \%$ banana pseudostem scutching waste improves WSA and available nutrients of soil after harvest of cabbage.

\section{References}

Angers, D. A. and Carter, M. R. (1996). Aggregation and organic matter storage in cool, humid agricultural soil. In "Structure and organic matter storage in agricultural soils". CRC press: Boca Raton., pp. 193-211.

Anonymous (2013). AGRESCO Report, $9^{\text {th }}$ meeting of natural resource management, SWMRU, NAU, Navsari, pp. 01-15.

Anonymous (2014). Final report of NAIP Component-2 sub project "A value chain on utilization of banana pseudostem for fibre and other value added products". NAU, Navsari, Gujarat, India.

Black, C. A. (1965). Methods of soil analysis Part I and II Am. Soc. Agron., Wisconsin, U.S.A.

Chatterjee, R. and Bandyopadhyay, S. (2014). Studies on effect of organic, inorganic and biofertilizers on plant nutrient status and availability of major nutrients in tomato. Internat. J. Bio-resource \& Stress Management, 5(1): 093-097.

Chaudhary, I. A. and Cornfield, A. H. (1966). The determination of total sulphur in soil and plant material. Analysis, 11: 528-530.

Jackson, M. L. (1973). Soil Chemical Analysis. Prentice Hall of India Pvt. Ltd., New Delhi, India.

Kanwar, K. and Paliyal, S. S. (2005). Effect of integrated nutrient management on growth and yield of cabbage. Himachal $J$. Agric. Res., 31(1): 15-20.
Leninraja, D. (2013). Effect of bio compost on soil chemical properties and nutrient uptake in paddy (Oryza sativa L.) under high $\mathrm{pH}$ soils. International exhibition and conference on water technologies, environmental technologies and renewable energy. 13-14 Feb., Mumbai, India.

Lindsay, W. L. and Norvell, W. A. (1978). Development of a DTPA soil test for zinc, iron, manganese and copper. Soil Sci. Soc. Amer. J., 42: 421-428.

Olsen, S. R., Col, C. V., Watanabe, F. S. and Dean, L. A. (1954). Estimation of available phosphorus in soil by extraction with sodium bicarbonate. Circ. U.S. Dep. Agric., 939.

Panse, V. G. and Sukhatme, P. V. (1967). "Statistical Methods for Agricultural Worker", Indian Council of Agricultural Research, New Delhi, India, pp. 152-161.

Patel, H. M. (2010). Effect of different level of SOC and fertilizer dose on yield of cabbage (Brassica olerecea L. var. Capatata) and soil properties. Ph.D. Thesis, Navsari Agricultural University, Navsari.

Prativa, K. C. and Bhattarai, B. P. (2011). Effect of integrated nutrient management on the growth, yield and soil nutrient status in tomato. Nepal J. Sci. \& Technol., 12: 23-28.

Sharma, J. P., Rattan, P. and Kumar, S. (2012). Response of vegetable crops to use of integrated nutrient management practices. ISABB J. Food Agric. Sci., 2(1): 15-19.

Subbiah, B. V. and Asija, G. L. (1956). A rapid procedure for the estimation of available nitrogen in soil. Curr. Sci., 25: 259-260.

\section{How to cite this article:}

Lokesh Kumar Saini, J.M. Patel and Rameti Jangir. 2018. Comparative Effect of Banana Pseudostem Scutching Waste, FYM and Biocompost on Water Stable Aggregate (WSA) and Available Nutrients in Soil after Harvest of Cabbage. Int.J.Curr.Microbiol.App.Sci. 7(05): 19781983. doi: https://doi.org/10.20546/ijcmas.2018.705.232 